\section{ENORMOUS WEIGHT OF A CHILD AT BIRTH.}

\section{To the Editor of THE LANCET.}

SIR :-I beg to forward you the following case which occurred in the conrse of my attendance on the patients of a public lyingin charity. I believe it refers to the largest foetus, perhaps, without exception, on record. Dr. Conquest gives the average weight of the foetus at seven pounds. The one which is described in the accompanying case weighed more than seventeen pounds. Yours, most obediently,

Haymoor, near Ludlow,

\section{J. D. Owens.} Nov. 12, 1838.

Mrs. R., a poor woman, residing in Pulteney-court, Little Windmill-street, was taken in labour at 8 o'clock, A.M., Nov. 6, 1838. She was a person of middle stature, square set, and of good health. The present made her six th accouchment. Her first child was still-born, after a lingering labour. In her fifth labour she brought forth twins, one of which was born dead. None of her children lived longer than sixteeu months, and all of them were remarkable for size and length. She stated that she had experienced - periodical labour-pains every evening for the past fortnight. She supposed that she had gone beyond the usual period of uterogestation; the catameuia had ceased to appear in the first fortnight of January last, being forty two weeks since the absence of that secretion. We found her in the erect posture, supporting herself by the bedstead. The membranes had been ruptured about an hour, and the liquor amnii had been discharged in considerable quantity ; it was of a greenish-yellow colour, apparently from the admixture of meconium. Uterine action was slow and feeble, with intervals of three minutes. Having satisfied ourselves that the head presented, we went away, requesting to be sent for directly the pains became more decided.

At 4, P.M, we were again sent for; the uterus was now in full action. The usual examination detected the head at the outlet of the pelvis, but its long diameter was not exactly in correspondence with the long diameter of the outlet : it was placed somewhat obliquely, having the right ear corresponding to a point midway between the symphysis of the pubis and the tuber ischii of the left side, the sagittal suture, of course, not being in the median line of the sacrum. As each successive pain forced the scalp on the perineum we made every exertion to correct the presentation, trusting the energy of the uterine system yet remaining would expel it, although we were aware of the large-sized head of the fostus, and its highly ossified condition; but the hand alowe could not effect it, for the sense of touch was soon benumbed. This state of things having existed for five hours we requested the assistance of Mr. William Bloxam, lecturer on midwifery, who, by means of the vectis, brought the head of the child into the pro. per position, and a few pains more accomplished the delivery. The correction was readily effected by introducing the vectis over the head of the child, behind the left ear, and placing the index-finger of the left hand on the right side of the forehead; then, by depressing the occiput with the instrunient, and at the some time elevating the furehead, the head was cansed to rotate in such manner as to throw the forehead into the hollow of the sacrum, and place the occiput exactly benealh the symphysis pubis. It was thus reduced to a natural presentation. The crown of the head now protruded through the os externum, but uterine action was so much exhausted that we had to wait an hour ere the head was expelled. The width of the shonlders now presented a new obstacle ; we therefore, after some dificulty, brought down an arm, but forty minutes more elapsed before the child was disengaged from the mother. During this tedious and trying occasion stimulants were given freely. The child exhibited no signs of life, and appeared to have been dead some hours. The funis was dark and livid, and it was coiled over the right shonlder, again round the body, and passed away over the right ankle. The perineum escaped uninjured. The placenta, after considerable delay, and we had employed every means to cause the uterus to contract, was expelled by the natural efforts. It exhibited the same hypertrophied condition (if we may use the expression) as was remarked in the overgrown child. Hemorrhage, which threatened to be severe, yiclded to the usual means. The woman was now composed by an opiate dranght, after a labour of sixteen hours duration, and is now doing remarkably well. A few piles, and some difficulty in making water, were noticed on the second day, which admitted palliation by simple treatment.

We add the weight and admeasurement of the child, as taken ten hours after delivery :-The long diameter, from the occiput to the root of the nose, $7+\frac{1}{4}$ inches; the occipito-mental, $8 \frac{1}{2}$ inches; from the parietal protuberances, 5 inches; the circumfer. ence of the skull, $15 \frac{1}{4}$ inches; the circumference of the thorax over the xyphoid cartilage, $14 \frac{2}{2}$ inches; the breadth of the shoulders, $7 \frac{1}{4}$ inches; the extreme length, 24 inches. The weight, seventeen pounds, twelve ounces. 